\title{
Linguistics in Premodern India
}

\author{
Émilie Aussant \\ CNRS UMR 7597 HTL, Univ. Paris Diderot, Sorbonne Paris Cité, Paris, France
}

\begin{abstract}
Summary
Indian linguistic thought begins around the $8^{\text {th }}-6^{\text {th }}$ centuries $\mathrm{BC}$ with the composition of Padapāthas (word-for-word recitation of Vedic texts where phonological rules are not applied). It took various forms over these twenty-six centuries and involved different languages (Ancient, Middle and Modern Indo-Aryan as well as Dravidian languages).

The greater part of documented thought is related to Sanskrit (Ancient Indo-Aryan). Very early, the oral transmission of sacred texts - the Vedas, composed in Vedic Sanskrit - made it necessary to develop techniques based on a subtle analysis of language. The Vedas also-but presumably later - gave birth to bodies of knowledge dealing with language, which are traditionally called Vedāngas: phonetics (śikșā), metrics (chandas), grammar (vyākaraṇa) and semantic explanation (nirvacana, nirukta). Later on, Vedic exegesis (mīmāms $\bar{a}$ ), new dialectics (navya-nyāya), lexicography (nighanțu and later, kośa) as well as poetics (alamkāra) also contributed to linguistic thought.

Though languages other than Sanskrit were described in premodern India, the grammatical description of Sanskrit - given in Sanskrit-dominated and influenced them more or less strongly. Sanskrit grammar (vyākarana) has a long history marked by several major steps (Padapātha versions of Vedic texts, Aștāadhyāȳ of Pāninini, Mahābhāṣya of Patañjali, Bhartṛhari's works, Siddhāntakaumudī of Bhaț̣oji Dīkșita, Nāgeśa's works) and the main topics it addresses (minimal meaning-bearer units, classes of words, relation between word and meaning/referent, the primary meaning/referent of nouns) are still central issues for contemporary Linguistics.
\end{abstract}

\section{Keywords}

Ancient Indo-Aryan, Dravidian languages, Middle Indo-Aryan, Modern Indo-Aryan, Padapātha, premodern India, Sanskrit, Vedāngas, vyākaraṇa.

\section{Overview of linguistic thought in premodern India ${ }^{1}$}

\subsection{Vedic literature and Padapāthas}

The most ancient Indian texts which have come down to us are the Vedas ("Knowledge"), composed in Vedic Sanskrit (Old Indo-Aryan; for a general presentation of the stages of IndoAryan, see Cardona and Jain 2007: 6-18). They constitute the foundational corpus of the Vedic religion, the most ancient form of Brahmanism, which is the starting point for numerous doctrines of premodern India. These texts, the most ancient of which go back to the second half of the second millennium BC, are different in form as well as in content and share the feature that they are based on a "revelation" (śruti, literally "hearing"). The Vedas include the samhitās, which are versified "collections" gathering together hymns, prayers, ritual incantations, as well as commentaries on these samhitās. There are four kinds of samhitās: 1) stanzas ( $r c)$ which make up the Rksamhitā or Rgveda (RV hereafter), 2) ritual incantations (yajus) gathered together (with or without commentary) in the Yajuhsamhitā or Yajurveda, 3) songs (sāman) of the Sämasamhitā or Sämaveda and 4) spells (atharvan), which constitute

\footnotetext{
1 "Premodern India" means India before the arrival of European theories and practices (see Pollock 2007: 8-10).
} 
the Atharvasamhitā or Atharvaveda. The Vedic - and also Brahmanical-tradition staunchly revolves around these four Vedas (cf. Renou 1947: 12).

This Vedic literature was composed and passed down orally. ${ }^{2}$ This practice left a deep mark on Indian culture, its relation to texts and, above all, its beliefs regarding language. Very early, the oral transmission of holy texts made it necessary to develop techniques based on a subtle analysis of language. One of the most ancient techniques involved the accurate description of phonological rules that apply at word junctures (sandhis) to move from continuous recitation (samhitā-pātha) of a samhitā - where rules are applied-, to word-forword recitation (pada-pātha) — where rules are not applied. This implies, on the one hand, an advanced knowledge of phonetics and phonology as well as, on the other hand, sophisticated thinking about how to parse continuous speech.

Consequently (and because no more ancient documents have come down to us), one traditionally considers that linguistic thought in premodern India began with the composition of Padapāthas, around the $8^{\text {th }}-6^{\text {th }}$ centuries BC. The Padapātha's ultimate goal was to preserve Vedic texts by drawing attention to those parts of the texts which were those most subjected to modifications, such as the word-final position (see Jha 1992: 14). They consist of versions of Vedic texts where some sandhis are dissolved and replaced by pauses; as a consequence, some linguistic units - the padas - are isolated. As such, the Padapäthas represent the earliest available grammatical commentaries of the Vedic samhitās (Abhyankar \& Devasthali 1978: XVIII, among others) and the pada-units they identify are the most ancient linguistic category (cf. $\S 2.1 .1$ for more details).

\subsection{Vedānigas}

The Vedas also gave birth to bodies of knowledge dealing with language which are traditionally called Vedängas ("Limbs [for preserving the body of] the Vedas"). They differ from the Vedas in that they are based on the "[tradition relying on] memorization" (smrti). The four Vedāngas related to language are traditionally ordered as follows: phonetics (śiksāa), metrics (chandas), grammar (vyākarana) and semantic explanation (nirvacana, nirukta). According to Scharfe (1977: 82), the delimitation of these disciplines occurred quite early: "Towards the end of the Vedic period there were thus three branches of linguistic study: phonetics (śikșa), etymology (nirukta) and grammar (vyākarana); but their oldest systematical works have not survived the hazards of oral tradition". And in fact one finds in Vedàngas' literature very old notions such as 'meter', 'metrical feet', 'word' and 'syllable' which demonstrate an exceptionally ancient thought regarding language and linguistic units (cf. Deshpande 2000: 137-138).

Phonetics $(s i k s ̦ \bar{a})$ aimed at preserving the correct pronunciation and recitation of Vedic texts, as well as at recomposing the continuous version of samhitās by applying phonological rules. Ancient Indian phoneticians accurately described the sounds (varna, i.e. vowels, svara, and consonants, vyañjana) according to 1) their accent (svara), 2) their duration (kāla), 3) their point of articulation (sthāna), from the glottis (kantha) up to the lips (oștha), 4) their manner of articulation (prayatna), including different degrees of contact and different degrees of openness, 5) their phonation (anupradāna), that is to say the quality of air passing through the glottal aperture. Moreover, ancient Indian phoneticians carefully accounted for features of junction (sandhi), as well as features of syllable-structure (length, quantity, tone). For more details, see Allen (1953), Pinault (1989: 304-313), Deshpande (2000).

\footnotetext{
${ }^{2}$ These texts were put in writing at a recent date (cf. Al Birûnî's record in the $11^{\text {th }}$ century which mentions a $V e d a$ recently transcribed in Kashmir).
} 
Metrics (chandas) gave instructions on the metrical structures of Vedic texts, that is to say set prosody's rules and described different types of metres (seven major metres and various complex structures).

Semantic explanation (nirvacana, nirukta) consisted of an elucidation of the meaning of difficult words, the goal being to attempt to find out how a word comes to mean what it does (cf. Kahrs 1998: xiv). Only one work belonging to the Nirvacana tradition (which presents itself as a complement to grammar) has come down to us, namely the Nirukta (N) - and its commentaries - which is attributed to Yāska and which was probably composed between the $5^{\text {th }}$ and the $2^{\text {nd }}$ century BC. Yāska's work is made up of, first of all, the commentary on vocabulary contained in lists of Vedic words known as Nighantu, lists which were very probably compiled from the padapătha versions of Vedic texts. This vocabulary constitutes the oldest Sanskrit lexicon (cf. §1.3). Yāska introduces his work by expounding some grammatical principles: he enumerates and briefly describes four classes of words (pada; nouns (nāman), verbs ( $\bar{a} k h y \bar{a} t a)$, prepositions (upasarga) and particles (nipāta)), he explains that nouns have substance (sattva) as their principal meaning while verbs have becoming $(b h \bar{a} v a)$ as theirs (several modifications of the "becoming" are listed) and he mentions the debate related to the verbal origin of nouns.

Grammar (vyākarana, action noun coming from the preverbed root $v y-\bar{a}-k r-$, traditionally interpreted as denoting a separation or a discrimination process of constituents; but it can also be taken as referring to a creation process, which generates, in a diversified way, the linguistic units; see Thieme 1982-1983: 11, 23-34 and Cardona 1997: 565-571) imparted knowledge, by describing their formation, of (correct) speech forms (see Cardona 1997: 543-544). Several schools of Sanskrit grammar developed in India, some of them being known only from quotations (see Scharfe 1977: 124-126). Their exact number is still unknown today (it fluctuates between 3 and 20, see Raghavan 1974: 272, 276), not only because (Indian as well as Western) scholars did not and do not always share a common conception of what is a school of grammar, but also because, for several reasons, much information has been lost over time (see Bronkhorst 2014).

Schools of Sanskrit grammar can be divided into two categories: the Pāninian school and the non-Pāninian schools. The fact is that Sanskrit grammatical thought was deeply influenced by the Asțāalhyāyz of Pānini, the earliest complete surviving Sanskrit grammar which dates from the $5^{\text {th }}$ century BC. During the following centuries, some grammarians decided to follow on the Pāninian work, creating in this way the Pāninian school, while others more or less moved away from this work (or were considered, by the Pāninian grammarians, as having moved away from it) and the techniques it implies.

The Pạninian school is indisputably the most ancient and the longest school of grammar in India (as well as in the world): it begins with Pānini's Aștâadhyāyz , the founding treatise of the school (cf. §2.1.2), and is traditionally considered to end with Nāgeśa (died in 1755 in Benares), a prolific grammarian whose erudite works marked the last renewal of the Panninian school (cf. §2.1.6). Several great scholars figured among this school (cf. §2.1.3 to 2.1.6) and a substantial amount of grammatical literature is linked to it (different kinds of commentaries and sub-commentaries but also independant treatises). The main reasons which explain why some grammarians moved away from Pānini's work is 1) the need for a more practical and pedagogical grammar and 2) a divergence of opinion regarding theoretical issues (such as the description of the formation of vrttis; on this point, see Cardona 2008).

The Asțāahy $\bar{a} y \bar{l}$ consists in a derivational model of a highly technical nature, made up of approximately 4,000 rules (sütra) and which includes numerous metalinguistic rules (metarules (paribhāșā), rules related to technical terms (samjiñ $\bar{a}-s \bar{u} t r a)$, headings (adhikāra)). That is how an arrangement of grammatical rules by topic (cf. §2.1.5) emerged, as well as a reduction (or even a suppression) of the metalinguistic tools and the removal of rules teaching 
purely Vedic forms. As far as one knows, grammars arranged by topic firstly appeared in the Buddhist and Jaina spheres (that is to say outside the Pạninian school which is of Brahmanical or Hindu tradition), after Sanskrit versions of their canonical texts were adopted.

The earliest attempt to organize grammatical rules by topic is Sarvavarman's Kātantra ("Small manual"), which probably dates from the $4^{\text {th }}$ century. This "practical" grammar, which is perhaps a recast of a more ancient one - the Kaumāralāta, see Scharfe 1977: 162influenced several later grammars, among which Kaccāyana's Pāli (Middle Indo-Aryan) grammar and the Siddhahaimacandra of the Jaina Hemacandra, and gave rise to a rich secondary literature (commentaries, supplements, etc.). The Kātantra school, while having been largely present in as well as outside India during centuries, retained its popularity in Kashmir, Nepal and parts of Bengal (Scharfe 1977: 163) from the revival of the Panninian school in the early $17^{\text {th }}$ century onwards (cf. \$2.1.5).

Another famous Sanskrit grammar arranged by topic, the Cāndravyākarana ("Candra's grammar"), composed by a Buddhist scholar - Candragomin - who would have lived during the $5^{\text {th }}$ century, is the basis of another grammatical school. The Candravyākarana is the first great recasting of Pānini's grammar (it also includes some of the additions suggested by Patañjali and Kātyāyana, the two first known commentators of Pāninin's work, cf. §2.1.3) as well as the great grammar of Buddhists. As such, it was widely circulated and was mainly preserved in places where Buddhism spread (Nepal, Tibet, Burma, Sri Lanka). For more details, see Belvalkar (1915: 57-62) and Scharfe (1977: 164-167).

Within the Jaina community, three grammars gave birth to three grammatical schools: the Jainendravyākarana of Devanandin $\left(5^{\text {th }}-7^{\text {th }}\right.$ centuries?), which is the most Pāninian of the non-Pāṇinian grammars (it preserves, among other, Pānini's generative scheme; see Belvalkar 1915: 62-68, Scharfe 1977: 168-169), the Śabdānuśāsana (or Śākațāyanavyākarana) of Śākațāyana, a grammar of the $9^{\text {th }}$ century arranged by topic (see Belvalkar 1915: 68-73, Scharfe 1977: 169) and the Siddhahemacandra (or Śabdānuśāsana) of Hemacandra $\left(11^{\text {th }}-12^{\text {th }}\right.$ centuries), another grammar arranged by topic, but more practical, which covers Classical Sanskrit and Prakrits (Middle Indo-Aryan; see Balbir 2000: notice 4336). Non-Pāṇinian grammars were also composed outside the Buddhist and Jaina communities, some of them being sponsored by princes like the Sarasvatīkanthāahharana of Bhoja, a grammar arranged by topic written in the $11^{\text {th }}$ century (see Scharfe 1977: 187-190).

\subsection{Other Sanskrit "language sciences"}

Thought about language occupied a central position in premodern India, in particular within the Brahmanical sphere where traditional scholars were firstly trained in grammar (Vyākaraṇa, cf. §2), Vedic exegesis (Mīmāṃsā) and dialectics (Nyāya). Up to the end of the first millennium, grammar and Vedic exegesis dominated the Brahmanical thinking about language. Around the beginning of the second millenium, along with the emergence of the Navya-Nyāya (new dialectics), the successor to the Vaiśeșika (systematics) and Nyāya classical schools, ${ }^{3}$ the dialecticians developped a theory of verbal cognition (śäbdabodha) which competed with grammatical and exegetical theories and influenced them (Gerschheimer 1996 I: 3).

The ultimate aim of Vedic exegesis (Mīmāmsāa) is to guarantee the correctness of ritual practice. In concrete terms, this implies the explanation of the meaning of Vedic utterances (in

\footnotetext{
${ }^{3}$ The foundation text of Nyāya was composed at the beginning of the first millenium. Up to the $11^{\text {th }}$ century, it is the "classical period" of the discipline (opponents are Buddhist logicians). The work of Udayana constitutes the culmination point of this classical period; it effects, among others, the quasi-fusion with another philosophical system, the Vaiśeșika, which aims at classifying real entities (padārtha). Navya-Nyāya emerges with the Tattvacintāmaṇi of Gañgeśa and, from then on, the opponents are exegetes. See Matilal 1977 for more details.
} 
particular, injunctive sentences) and then the resolution of numerous interpretative problems in Vedic texts. This task led Sanskrit exegetes to deal with, among other issues, the words and sentences expressing injunctions, the nature of the word and the sentence in general, the nature of their respective meanings (see McCrea 2000 and David (to be published) for details. Recent general surveys of the discipline: Jha 1942, Verpoorten 1987). It is interesting to note, with McCrea (2000: 429), that: "While the primary focus of attention in Mīmāmsāa is on Vedic texts, the hermeneutical principles developed in the course of analyzing these texts are formulated so as to be applicable to language in general, and are recognised as such by scholars in other fields. For this reason, Mīmāṃsā is frequently designated as vākya-śāstra ("the science of sentences")."

The new dialectics (Navya-Nyāya) is firstly a theory of the means of acquiring valid knowledge (pramāna) among which speech (śabda) plays a prominent role (cf. Gerschheimer 1996 I: ix). Within this frame, Sanskrit dialecticians addressed such topics as: the notions of speech and word, the production of verbal knowledge, the meaning of a word, the nature of the relation between a word and its meaning as well as the problems caused by tropes and corrupted forms, the acquisition of the relation between a word and its meaning, the sentence and the syntactic link. For a general presentation of this discipline (Vaiśeșika, early Nyāya school and Navya-Nyāya school), see Matilal 1977; for an overview of the naiyāyika theory of speech, see Gerschheimer 1996 I: 43-99.

Lexicography (Nighaṇțu and later, Kośa) as well as poetics (Alạ̣kāra) may also be considered part of the Sanskrit "language sciences".

Classical Sanskrit lexicography (Kośa) ${ }^{4}$ played an important role in Indian scholarship, especially poetry: the aim of classical lexica, which were learnt by heart, was to help poets in composition, where synonyms of varying syllable structure are required to satisfy metrical constraints. Two main kinds of lexicon (kośa) were composed: synonymic (ekārtha, samānārtha), where words are classified according to subject (e.g. words relative to heaven, sky, time, thought, sound, etc.), and homonymic (anekārtha, nānārtha), which list words having more than one meaning (for more details regarding lexicography, see Vogel 1979 and Patkar 1981; for more details regarding the opposition between synonyms and homonyms or polysemous words, see Aussant 2014a). Note that from the $11^{\text {th }}$ century onwards, bilingual and multilingual dictionaries were composed (Sanskrit-Kannada, Sanskrit-Kawi, SanskritMarathi-Telugu-Persian, among others). Lexica in Prākrit as well as in Pāli (Middle IndoAryan languages) were also composed.

Sanskrit poetics (Alaṃkāra) is an erudite discipline that accompanied Sanskrit literary production (mainly $k \bar{a} v y a$, the refined poetry) for nearly two millennia. It addressed, among other questions, the following issues: analysis of the formal, logical, semantic and pragmatic aspects of simile and other tropes; word classes; word meanings (denotation, metaphor, suggestion); sentences, passages and whole literary works' meanings, language registers. For a general study of poetics, see De 1960, Gerow 1971, Bronner 2012.

\section{4. "Extended" Sanskrit Grammar}

A noteworthy fact is that Sanskrit grammar, like Greek, Latin and Arabic grammars, has been transferred or "extended" (see Auroux 1992: 11-64 and Auroux 1994) to languages other than the one it was originally designed to describe (i.e. Sanskrit). Indeed, some grammatical descriptions elaborated for Sanskrit were used (to varying degrees and in different ways) for the description of various languages mainly in India (Middle and Modern Indo-Aryan

\footnotetext{
${ }^{4}$ The most ancient lexicon which has come down to us, the Nāmalingānnuśāsana of Amarasiṃha, would have been composed around the $6^{\text {th }}$ century.
} 
languages as well as Dravidian languages and Persian) but also in Tibet, South-East (Burmese, Old-Javanese) and Central Asia (Buriat), as well as in the West (Algonquian languages). If grammatical descriptions elaborated for Sanskrit played a major role in the history of the grammaticization of different languages, it is undoubtedly because they associated, on the one hand, an incredibly powerful and sophisticated grammatical model (or analyses, cf. §2.1.2) to a highly prestigious language (first, the language of holy texts, the Vedas, then the language of a technical literature and then, in the first millennium, the cosmopolitan (literary as well as political) language of an ever-increasing area, see on that point Pollock 2007). Indeed, it seems that the transfer of Sanskrit grammatical descriptions to languages other than Sanskrit is always linked, in one way or in another, to the power of Sanskrit grammatical descriptions or to the prestige of the language or, even, to both. That being said, the "extension phenomenon" of Sanskrit grammatical descriptions has been achieved in a wide variety of ways.

One of its manifestations is that Sanskrit grammar serves as a "source grammar" for "indirect grammars" (or "transfer grammars" according to Harris 1954, p.260). For instance, the grammars of Prakrits (Middle Indo-Aryan languages, cf. §1.5) have been conceived as appendices to Sanskrit grammar: 1) the general structure of their rules is "instead of $x$ (Sanskrit form), one has $y$ (Prakrit form)"; 2) for any linguistic fact which has not been described in the grammar, the user is taken back to the Sanskrit norm (e.g. the last aphorism of the Präkrtaprakāśa states śeșāh samskrtāt "the rest [is to be inferred] from Sanskrit"; for more details, see Nitti-Dolci 1938 and Balbir 2000: notice 4331, notice 4335, notice 4340). Such a description of Prakrits, which is clearly contrastive, assumes that these languages were considered as vikrtis, "modifications" (probably, at some time, as distortions), of Sanskrit. In the case of Prakrits, it really corresponds to a historical development, but it is not the case of other language descriptions. The Pārasīprakāśa of Kṛṣnadāsa, for instance, which was written at the request of Emperor Akbar (ruled 1556-1605), describes Persian forms from the Sanskrit norm, though neither language is derived from the other (see Scharfe 1977: 196). Another example is the Lìlatilakam, a $14^{\text {th }}$ century poetical manual which devotes two chapters to the grammatical description of Manipravālam, the mediaeval literary language of Kerala, which is defined as a mixture of the Kēralabhāșā (the mediaeval form of Malayālam, a Dravidian language) and Sanskrit (cf. §1.6). Though the general organisation of the Lìlatilakam is deeply different from Prakrit grammars, one finds occasional mention of counterexamples which would be generated if some Pānininian rules were applied (i.e. "if one would apply such [Pāninian] rule, one would obtain such form which is not considered as correct in the Kēralabhāṣā"; see Aussant 2012). Sanskrit grammatical rules are thus never far away, even in some descriptions of Dravidian languages.

Another manifestation of the "extension phenomenon" of Sanskrit grammatical descriptions is the use of technical devices, terminology and/or of concepts initially created for the description of Sanskrit. An example of the extension of a Sanskrit technical device is provided by two basic treatises of the Tibetan grammatical tradition, the SCP (Sum-cu-pa) and the TKJ (Rtags-kyi-'jug-pa), two short versified texts, the dating $\left(7^{\text {th }}-9^{\text {th }}\right.$ centuries?) and authorship of which are problematic (Miller 2000, Verhagen 2000a). Verhagen (2000b: 211, 2001: 229-230, 233-235) notes that these texts resort-far less extensively-to ellipsis (Sanskrit anuvrtti), that is to say to the tacit recurrence of one or more elements of one grammatical rule in subsequent rules. Regarding grammatical technical terms, one may give the example of Tamil grammatical terminology which, according to Chevillard (2000d: notice 4351), was often modelled on or adapted from Sanskrit terminology though some terms or expressions seem to indicate the existence of a former indigenous metagrammatical terminology (cf. §1.6). Sanskrit influence has been more or less significant depending on the period. It is particularly noticeable in the Viracolliyam, a Tamil grammar of the $11^{\text {th }}$ century 
written by a Buddhist Tamil grammarian. Chevillard (2000c: 201 and 2000d: notice 4353) notes, among other things, that the grammar borrows massively from the Sanskrit metalinguistic vocabulary: "[...] canti, upakārakam, tattitam, tātu, kiriyā patam and alainkaram are in effect the adaptations to the phonology of Tamil of the terms sandhi ["junction"], upakāraka ["auxiliary"], taddhita ["secondary suffix"], dhätu ["root"], kriyā pada ["verb"] and alamkāra ["[rhetoric] ornament"]." If one looks at the use of the term tattitam for instance, one observes (thanks to Jean-Luc Chevillard 2009: 211-212) that it denotes a linguistic fact close to the one described by the taddhita of Sanskrit grammarians. An example of conceptual extension is provided by the adoption of a semantic classification of the grammatical object, initially formulated by Bhartrhari, a Sanskrit grammarian of the Pāninian school of the $5^{\text {th }}$ century (cf. §2.1.4), by Cēnāvaraiyar, a $13^{\text {th }}-14^{\text {th }}$ Tamil commentator of the Collatikäram ("The Book of Words") of the Tolkappiyam (cf. §1.6). The Sanskrit description (such as found in the Asțâdhyāy $\bar{l}$ of Pānini) distinguishes semanticsyntactic categories (käraka) from the linguistic forms which express them. Bhartrhari expounds a sevenfold classification of the karman ("object"), from which Cēnāvaraiyar keeps only three categories which end up having a purely semantic value (for one type cannot be distinguished from another on the basis of Tamil morpho-syntactic features; on this conceptual borrowing, see Vergiani 2013). For more details on "extended" Sanskrit grammar, see Aussant (2017).

This transfer of Sanskrit grammatical descriptions occurred outside Asia as well. Mention should be made of Leonard Bloomfield, who was deeply inspired by the Pāninian descriptive model (see notably his 1933 book Language) and used some of Sanskrit grammatical concepts in his description of Algonquian languages (cf. Rogers 1987, Emeneau 1988).

\subsection{The grammatical descriptions of Middle and Modern Indo-Aryan languages}

There are a diverse range of records of Middle Indo-Aryan languages (see Cardona and Jain 2007: 12-18): early Middle Indo-Aryan is attested by Aśoka's inscriptions (mid $3^{\text {rd }}$ century $\mathrm{BC}$ ) and by Theravāda Buddhist texts in Pāli; later stages are attested by various literary or grammatical works composed in (or describing the) different Prākrits. According to Cardona and Jain (2007: 8), there is evidence of the modern stage of Indo-Aryan as early as the $12^{\text {th }}$ century.

The most ancient grammar of a Middle Indo-Aryan language known to us is the Prākrtaprakāśa of Vararuci, which was probably written between the $3^{\text {rd }}$ and the $5^{\text {th }}$ centuries. This work deeply influenced later Prakrit Grammarians, those of the Eastern school, that is to say Puruṣottama, Rāmaśarman and Mārkaṇdeya, who are his direct successors, but also those of the Western (or South, see Nitti-Dolci 1938: 179) school, the master of which would have been Hemacandra. Prakrit grammars mainly differentiate themselves 1) by the dialect(s) they describe (Vararuci's Prākrtaprakāśa primarily describes the Mahārāṣtrīi, the Prakrit "par excellence", and devotes a very few sūtras to Paiśācī, Māgadhī and Śaurasenī; Hemancandra's Śabdānuśāsana-1 $1^{\text {th }}-12^{\text {th }}$ centuries-describes Sanskrit, Mahārāșțrī, Śaurasenī, Māgadhī, Paiśācī, Cūlikāpaiśācī and Apabhraṃśa) and 2) by the way they classify them. The Eastern school of Prakrit grammarians is characterised by the following features: 1) the study of the same languages, which are classified as bhāsa (dialects mainly used in stageplays by high-ranking characters), vibhāssā (dialects used in stage-plays by low-ranking characters, see Grierson 1918: 516), apabhramśa (dialects spoken by cultured persons and/or used by poets) and paiśácika (dialects used in tales according to Nitti-Dolci 1938: 126); 2) a large part of these grammars is devoted to Mahārāșțīi, the description of which is the basis for the description of the other Prakrits; 3) Vararuci's description of Mahārāsțtrī is strictly followed. The unity of the Western/South school is less easy to grasp (see Nitti-Dolci 1938: 
179-194). The vast majority of Prakrit grammars are written in Sanskrit and are conceived as appendices to Sanskrit grammars, allowing for Prakrit units-which are considered to be modified forms (vikrti) of Sanskrit - to be formed from Sanskrit (cf. §1.4). Pāli grammars, though subject to the influence of Sanskrit grammars-Pānini's Aștāadhyāyzi, Śarvavarman's Kätantra, Candragomin's Cāndravyākaraṇa-do not teach Pāli units as modifications of Sanskrit forms, probably because Sanskrit is less important than Pāli for the Buddhist communities of the Theravāda tradition (cf. Scharfe 1977: 195).

Modern Indo-Aryan languages were given grammatical descriptions in a much later period and mostly on the initiative of foreigners. However, some works deserve to be mentioned, such as 1) the Uktivyaktiprakarana, a bilingual Sanskrit-Old Kosali manual (which gives, for the first time, an overview of the Old Kosali grammar), written in the $12^{\text {th }}$ century by Dāmodara (see Salomon 1982); 2) the Varnaratnākara by Tyotirīsvara Kavisekharācārya, the first grammar of Maithilī composed in 1507 (see Bhatia 1987: 21); 3) the grammar of Braj Bhāṣā written (in Persian) before 1676 by Mirzā Khān-ibn-Fakkru-u-Dīn (see Bhatia 1987: 17-21). A noteworthy point is that some grammars of Modern Indo-Aryan languages written by Indian scholars - whether or not preceded by grammars composed by foreigners - have followed the model of Sanskrit grammars (e.g. the Mahārāștraprayogacandrikā (grammar of Marathi) of Veṅkața Mādhava (1827), the Kaśmīraśabdāmṛta (grammar of Kaśmiri) of İśvara Kaula (1875), the Mithilābhāṣāvidyotana (grammar of Maithili) of Dinabandhu Jha (1946)). This is another manifestation of the "Extended Sanskrit Grammar" phenomenon (cf. §1.4).

Note that several studies on the history of the grammaticisation of Modern Indo-Aryan languages have been carried out, such as Arjunwadkar 1992, Bandyopadhyay 2011, Bhatia 1987, Mone 1927, Shapiro 2000.

\subsection{The grammatical descriptions of Dravidian languages}

Dravidian languages (Tamil, Telugu, Kannaḍa and Malayālam) were equally the subject of native grammatical descriptions, ${ }^{5}$ more or less ancient and more or less autonomous.

Among these Dravidian grammatical descriptions, the Tamil tradition is the most ancient: it emerged at the beginning of the Common Era in South India. The language of description was classical Tamil and the object of description was mainly poetry (see Chevillard 2000a). The most ancient Tamil grammatical text which has come down to us is the Tolkappiyam $\left(5^{\text {th }}\right.$ century?). It consists in three books: 1) the "Book of Letters" (Eluttatikāram), which is devoted to phonetic, phonological and morphophonological observations and which contains notes regarding writing; 2) the "Book of Words" (Collatikāram), which provides the description of some morphosyntaxic facts, such as cases; 3) the "Book of [poetic] topics" (Porulatikāram), which describes the various items of Tamil poetics (see Chevillard 2000b). The grammatical texts composed after the Tolkäppiyam are either commentaries of the Tolkāppiyam or independent texts, among which some were more innovative than others (such as the Viracōilyam, $11^{\text {th }}$ century) and some had a more important influence than others (such as the Nannūl, 13 ${ }^{\text {th }}$ century). For more details, see Scharfe (1977: 182-183), Subrahmanya Sastri (1997) and the numerous works carried out by Chevillard (such as Chevillard 2000c). One should notice that Tamil grammatical thought has been influenced by Sanskrit grammar (cf. §1.4), particularly in terms of the classification of items (see Scharfe 1977: 181), terminology (see Chevillard 2000c: 201) and concepts (see Vergiani 2013). For more details concerning the influence of non-Tamil models on Tamil grammar, see Meenakshisundaram (1974).

\footnotetext{
${ }^{5}$ As they were the subject of grammatical descriptions by foreigners and, among them, missionaries (see Zwartjes 2011 and Zwartjes \& Pytlowany forthcoming).
} 
It is often claimed that the Telugu grammatical tradition started in the $11^{\text {th }}$ century, with the composition, by the poet Nannaya, of a Sanskrit grammar of Telugu titled Āndhraśabdacintāmani. However, scholars now generally believe that this text was written in the $16^{\text {th }}$ century. Therefore, the very first Telugu grammar written in Telugu would be the $\bar{A} n d h r a b h \bar{a} s \bar{a} b h \bar{u} s a n a m u$, composed by Ketana in the $12^{\text {th }}$ century. In both works, great significance is attached to the different kinds of words (tajja "derived either from Sanskrit or Prakrit", samā "similar either to Sanskrit or Prakrit", deśyā (lit. "regional") "pure Telugu", grāmyā (lit. "related to villages") "rustic language which is not bound by the grammatical rules" according to Nannaya; see Sarveswara Sharma 1973: 385-386). Such a classification of Telugu words implies that the language was conceived as a modified form of Sanskrit, like a Prakrit (see Hock 2016: 717). Mention should also be made of the composition, in the $19^{\text {th }}$ century, of Paravastu Cinnayasūri's Bālavyākaraṇamu, an influential grammatical treatise in Telugu where sütras are organized by topic (cf. §1.2). For more details on the Telugu grammatical tradition, see Purushottam (1996).

The Kannada grammatical tradition begins in the $12^{\text {th }}$ century with two treatises written by Nāgavarma (who mentions earlier grammatical works which have not survived): the Śabdasmrti, which is in Old Kannaḍa and which constitutes a part of the Kāvyāvalokana, a poetical work, and the Karnạtakabhāṣābhūṣana, which is an independant work in Sanskrit sütras (see Scharfe 1977: 186). Other works would follow, some composed in (Old) Kannada, such as Keśirāja's Śabdamaṇidarpaṇa (13 ${ }^{\text {th }}$ century) and Kṛ̣nạamācārya's Hosagannada nuḍgannaḍi (19 ${ }^{\text {th }}$ century), which studies the links between Kannaḍa, Sanskrit and Tamil; another work, the Karnātakaśabdānuśāsana of Bhațāalkalanka Deva (17 ${ }^{\text {th }}$ century), was composed in Sanskrit and influenced by Jainendra's grammar (see Scharfe 1977: 186). For more details on the Kannadia grammatical tradition, see Kulli (1991) and (1997).

The oldest known grammatical observations related to Malayālam are found in a poetical treatise of the $14^{\text {th }}$ century, the Lìlatilakam. This text, composed of Sanskrit sütras, describes - among other things-morphological and phonological characteristics of Manipravālam, the mediaeval literary language of Kerala (a mixture of the Keraḷabhāșā and Sanskrit). The defining characteristic of this treatise is that it mainly establishes a relationship of combination between both languages, not a relationship of contrast or modification (see Scharfe 1977: 184, Aussant 2012): the sentences combine Sanskrit and Keralabhāșā words, which keep their respective endings according to their respective syntax. Like the combination of the languages which are described, the Lillatilakam blends descriptive models: one observes features coming from Sanskrit as well as Tamil grammars (see Scharfe 1977: 185, Aussant 2012: 92-99). Some other grammatical works related to Malayālam were written after the Lilatitilakam, such as the Kerala Kaumudi (1878) by T.M. Kovunni Nedungadi, which was conceived as an aid for writing literary works and which equally associates Sanskrit and Tamil grammars, and the Keraḷ Pạninīyam (1896), a successful work by A.R. Rajaraja Varma which, after having presented the history of Malayālam (as a Dravidian language influenced by Sanskrit), describes it — in modern Malayālam - drawing his inspiration from the Pạninian system. For more details on the Malayālam grammatical tradition, see Ezhuthachan 1975.

\section{Sanskrit Grammar (vyākaraṇa)}

\subsection{Major steps}

\subsubsection{Padapāthas}

As mentioned in $\S 1.1$, one traditionally considers that linguistic thought in premodern India began with the composition of Padapatthas, around the $8^{\text {th }}-6^{\text {th }}$ centuries BC. Padapāthas 
represent the earliest available grammatical commentaries of the Vedic samhitās (see, for instance, Abhyankar \& Devasthali 1978: XVIII) and the pada-units they identify are the most ancient linguistic category. No grammatical text composed by the authors of Padapathas is available to us. Thus, it is from the criteria they adopt for the isolation of pada-units that we can reconstruct the linguistic principles they follow and therefore their conception of pada.

The analysis performed by Padapathas is based on "phonological criteria that involve syntactic units" (Cardona 2012: 53): they identify sandhis occuring in specific places within continuous speech and replace them by pauses of two kinds: 1) one pause graphically marked by "|", which corresponds to a silence two morae in length (e.g. agním $|\bar{i} l e|$ puráh-hitam | from agním ịle puróhitam (RV 1.1.1) "I praise Agni set at the fore"), 2) one pause graphically marked by "-", which corresponds to a silence one mora in length (e.g. agním | ìle | puráhhitam |). The two-pause distinction reveals a subdivision of the pada-category: the category of external padas, marked by "|", and the category of internal padas, marked by "-". This subdivision of the pada class is explained by the distinction between two kinds of junction: a word-junction in the first case and a constituent- or a morpheme-junction in the second case. Both kinds of pause are generally made where the phonetic alterations Western scholars call "external sandhi" apply (cf. Macdonell 1995: 20). The places within continuous speech where these phonetic alterations occur were perceived, and then analysed, as corresponding to the end of a specific linguistic unit identified by the name pada.

The analysis of some sequences, especially compounds, reveals two more features of padaunits. First, as already noted by Cardona (2014: 91-92), the fact that the break is made only at the last junction of the derivation and even where there is no phonetic alteration, as in prajápatih (R. 4.53.2 "master (-patih) of creatures (prajáa-)", which is composed of three units pra-, $j \bar{a}$ - and pati-), indicates that authors of Padapathas conceived of padas as syntactic units, that is to say as "segments terminating with nominal or verbal endings or which, in a derivational system, at one point contained such endings" (italics are mine). ${ }^{6}$ This is confirmed by the fact that, if the first member (or both members) of a compound is not used independently in the RV, it is not analysed in Padapāthas (see Jha 1992: 173). Hence, Padapāthas authors' conception of padas is based on phonological as well as derivational considerations. ${ }^{7}$ Second, as shown by Abhyankar (1974:10), breaks in compounds occur when the constituent parts are considered capable of expressing their separate meanings individually. Hence, there is no break in compounds used as proper names, such as viśvámitra (RV 3.53.9). Therefore, padas are considered as meaningful units.

Pānini, who mentions Sākalya, the author of the Padapātha of the Rgvedasamhitāa, inherits the subdivision in external and internal padas (cf. Aussant forthcoming).

\subsubsection{The Aștāadhyāȳ of Pānini}

The founding text of Vyākaraṇa is the Aștādhyāȳ ("The Eight-Chaptered") of Pānini (5 $5^{\text {th }}$ century BC). Brahmin and subject of a satrapy of the Persian empire, Pānini presumably composed his grammar at a time when some of the foundations of the Brahmanical society were being questionned by emerging Buddhism and Jainism. These philosophico-religious trends challenged, among others things, the supremacy of the Sanskrit language which, in

\footnotetext{
${ }^{6}$ Secondary derivatives, which are analysed as derived from a syntactical pattern involving inflected forms, are submitted to the same analysis (e.g. gó-mān (RV 4.2.5), which is conceived as derived from gāvo 'sya santi "he to whom ('sya) cows ( $g \bar{a} v o$ ) belong (santi)").

${ }^{7}$ Note that Jha (1987: 20-23, 1992: 22-25), Kulkarni (1995: 9 et al.) and more recently Bhide (2015: 51) have pointed out the striking similarity which can be observed between the analysis adopted by authors of Padapatthas and the one achieved by the Western Immediate Constituents Analysis (ICA) — at the level of words, at least (Jha 1992: 67). The procedure is the following: if the case ending is not segmentable, the segmentation occurs before the previous constituent (e.g. prajá-vatịṣu (ṚV 7.1.11), where -su is not segmented because it follows a long vowel). If this second constituent is not analysable, the separation is applied to the previous constituent, etc.
} 
contrast to the Hindus, is not their holy language. Pạnini's treatise was the basis for the establishment of a school of grammar of the same name, creating an institution which - at least as far as we can see from the texts which have reached us-largely dominated up to the $18^{\text {th }}$ century. As for some other ancient Indian disciplines, the success of the Asta $\bar{a} d h y \bar{a} y \bar{\imath}$ eclipsed the works of other schools. Last but not least, Pāninin's grammar settles, during the centuries following its composition, the norm of a language later named Sanskrit.

This treatise consists of some 4,000 sütras ("aphorisms"; the term is generally translated by "rules") which made up the grammar stricto sensu. On a practical level, Pāninin's grammar provides abstract procedures for forming words (pada) with affixes (pratyaya); for more details, see Cardona (1980: 234-236). These affixes are directly introduced (under meaning conditions and co-occurrence conditions) in some of the 4,000 rules, unlike most of the bases with which they combine and which are either verbal roots (dhātu) or nominal bases (prātipadika). Verbal roots are listed in the Dhätupațtha ("recitation of verbal roots"), whereas nominal bases are introduced in diverse ways. Verbal and nominal bases constitute the two main formal starting points ${ }^{8}$ for the derivational process which is found throughout Pāninian rules, making it possible to generate more and more complex units up to correct Sanskrit sentences $(v \bar{a} k y a)$. For a concrete illustration of sentence derivation, see Pinault (1989). At first glance, the Aștâdhyāy $\bar{l}$ appears to have not been composed to be read from beginning to end: there is neither progression nor continuity in the linguistic facts it describes. Frequently, rules which are to be applied together are found in sections separated by several rules, or even by several sections. As a consequence, the word class definitions are not systematically followed by the operations (or "accidents") the classes undergo. Such a framework is explained by the fact that, except for the rules which strictly concern totally different groups of units (such as nouns and verbs) and for which the order of application is unimportant, the order of rules' application is mostly relevant. The fact remains that it is often governed, more than by the linguistic content, by: 1) the functions of the rules (general vs specificutsarga/apavāda -, necessary vs non-necessary - nityalanitya -, internal vs external - antaranga/bahir-ainga), 2) the fact that the application of one rule must precede the application of another rule, 3) the avoidance of repetition in the formulation of the rules. Whatever the explanation of the ordering may be, the core of Pạnini's grammar concerns the derivation of words (always within the context of a sentence), a topic treated in the third, fourth and fifth sections, those that are the most consistent from the point of view of the order of the rules.

The Asțtâdhyāy $\bar{\imath}$ of Pānini is the first attempt at a complete description of a language-which encompasses, within a synchronic perspective, the sacred language named chandas (i.e. Vedic Sanskrit) and the non-sacred common language named bhāṣa (i.e. classical Sankrit) - in the form of a generative grammar (cf. Gillon 2007), characterised by an extremely condensed formulation, a high level of formalism and very sophisticated metalinguistic tools (terms and devices). To give an example of Pāninian sūtra, one can quote the rule $i K o$ yaN $a C i$ " $y, v, r$ and $l$ are the substitutes of $i, u, r$ and $l$ before a vowel", where: 1$)$ the operation of substitution (which is a pivotal operation in the Asta $\bar{a} d h y \bar{a} y \vec{\imath}$ ) is indicated in the following way: the substitute is marked by the nominative case and the item which is substituted is marked by the genitive case (this technique makes it possible to avoid the use of a verb like "to replace"; 2) phonemes are denoted by abbreviations (pratyāhāra): $i K$ stands for $i, u, r$ and $l, y a N$ stands for $y, v, r$ and $l$ (thanks to the rule adir antyena saheta $(1.1 .71),{ }^{9}$ a certain number of abbreviations (the Ast $\bar{a} d h y \bar{a} y \bar{\imath}$ uses 41 of them) can be formed, like $a C$ which denotes the groups of vowels and $h a L$, the groups of consonants); 3) the right context of an operation is

\footnotetext{
${ }^{8}$ Note that the very first step, in the Pāninian derivational system, is a weak semantic level, closely related to syntax: nouns and verbs are derived bearing a clear relationship to the utterance of which they are a constituent (cf. Cardona 1997: 136-185).

9 “An initial item joined with a final marker denotes not only itself but also all intervening items".
} 
marked by the locative case: $a C i$ "before a vowel" (the left context is marked by the ablative case). For a detailed description of the Aștâdhyāyzi, see Cardona (1997).

\subsubsection{The Mahābhāṣya of Patañjali}

Patañjali $\left(2^{\text {nd }}\right.$ century BC) is the author of the Vyākaranamahābhāṣya ("The Great commentary on the analysis [of words]", more generally named Mahābhāsya). This monumental work quotes and discusses 4,300 vārttikas ("Remarks on the procedure" or scholia) composed by Kātyāyana, ${ }^{10}$ the most ancient commentary on Pāninin's grammar which has come down to us and which is known only through Patañjali's gloss. The Mahābhāssya, which takes the form of controversies between a student (śisya), a master who knows only a part of the topics addressed (ācāryadeśíya) and a master who establishes the final true view (ācārya, siddhāntin), concerns slightly more than 1,700 Pāninian sütras on the whole. Through these scholastic debates, the content as well as the validity of the sütras and of the värttikas is carefully studied; examples as well as counter-examples are given to illustrate them. The discussion ends with the acceptance or the rejection of Kātyāyana's amendments, when it is not left to the reader to draw the conclusion.

Patañjali is the latest member - hence embodies the highest authority —of what is traditionally called the "triad of wises" (munitraya), the first two members being Pāṇini and Kātyāyana (about this triad and the notion of authority in the Pạninian tradition, see Deshpande 1998). He is unanimously considered as the most prominent commentator of the Pāninian work. His Mahābhāsya, which is written in a simple but vigorous prose, constitutes a valuable dialectic instrument: thanks to it, the reader has access to the heart of Pāninian thought. Patañjali's work has been subjected to numerous commentaries, mostly incomplete, with the exception of Kaiyata's Pradīpa ("The Lamp [of the Great commentary]", $2^{\text {nd }}$ century). The Mahābhāṣya is a fundamental work because, on the one hand, it provides a "state of the art" of the questions related to language addressed at that time in the Brahmanical "milieu"11 and, on the other hand, it contains the seeds of the issues which will be thought of and discussed during the following centuries. For an overview of these issues, cf. Coward and Kunjunni Raja 1990 (115-119).

\subsubsection{The Vākyapadīya of Bhartrihari}

Bhartrhari ( $5^{\text {th }}$ century) is the author of the Vākyapadìya ("Work dealing with sentences and words") as well as of the Mahābhāsyadīpikā ("Light on the Great commentary"), the earliest commentary on the Mahābhāsya of Patañjali, which has survived in part. Bhartrihari is traditionally depicted as the philosopher of grammar. Considering himself a grammarian (of the Pāninian school), he indeed created an original philosophy which borrows various elements from other disciplines of his time (cf. Bronkhorst 1998c: 764). His philosophy, which implies that the study of grammar would provide access to salvation, ${ }^{12}$ goes well beyond the scope of grammar and deeply influenced later thinkers, Hindu as well as Buddhist. Bhartrihari would have written the Mahābhāsyadīpikā before the Vākyapadīya. In the latter text, the grammarian-philosopher adresses various topics which concern general Linguistics (such as the notions of sentence, word, action, tense, gender and number, the ways of understanding meaning, the meaning of linguistic units, the phenomenon of autonymy, etc.) as well as pure Sanskrit grammar (such as derivation, composition, etc.) in making reference to different positions defended at his time on the same topics. This perspectivist approach (the

\footnotetext{
${ }^{10}$ Patañjali nevertheless comments directly 468 Pāṇinian sūtras.

${ }^{11}$ Patañjali's thought was not influenced by the classical systems of Indian philosophy, "with the possible exception of Sarvāstivāda Buddhism" (cf. Bronkhorst 1998a).

${ }^{12}$ Cf. Cardona (1980: 300): "Grammar, as a means for discriminating correct (sādhu) from incorrect (asādhu, apabhramśa) usage, is a means of attaining ultimate release (apavarga), what we call salvation."
} 
views of other schools of thought are not brought in for the sake of refutation but in a spirit of accomodation, cf. Subramanya Iyer 1992: 75) is a salient feature of Bhartrihari's work, though Patañjali already paid attention to various points of view (cf. Cardona 2009: 121).

One of the key ideas in Bhartrhari's philosophy is that any whole is more real than its constituents. On the linguistic level, this means that, among the three classes of units which constitute language (varna "phoneme", pada "word", vākya "sentence"), only the sentence is the primary linguistic unit; phonemes, stems, suffixes and words are inventions of grammarians. Another key idea developped by Bhartrhari-but already formulated by Patañjali, though slightly differently and not on the same scale - is that linguistic units can be conceived of as different from the sounds that reveal them (cf. Bronkhorst 1998b: 382) and, as such, they are called sphoța. As noted by Subramania Iyer (1992: 160), the notion of sphota is the grammarians' answer to the problem raised by the understanding of a meaning from sounds which are uttered in a temporal sequence (and, therefore, which cannot cooperate to convey the meaning). Bhartrihari innovates in making sphota the meaning-bearer (cf. §2.2.1), thus inaugurating a long series of debates, inside as well as outside grammar (cf. Bronkhorst 1998b: 382-383). For an overview of arguments for and against the sphota resorted to in premodern India, cf. Gaurinath Sastri (1980); for more information on sphota, cf. Coward (1980) and Matilal (1990: 77-105).

\subsubsection{The Siddhāntakaumudī of Bhatțoji Dīkșita}

Bhattoji Dikșita (late $16^{\text {th }}$ century, early $17^{\text {th }}$ century) is one of the late major figures of the Pāninian school, which he helped to renew. He composed various works on different topics, four of which are related to grammar: the Śabdakaustubha ("The jewel of words"), which is a commentary on Pānini's Asțādhyāyzi; the Vaiyākaranamatonmajjana ("The advent of grammarians' views"), which consists in a collection of 76 stanzas dealing with syntax, semantics and philosophy of language; the Siddhantakaumudi ("The moonlight of the conclusions"), which is a re-arrangement of Pānini's Aștâdhyāy $\bar{\imath}$ with a commentary; and the Praudhamanorama ("The one which delights the spirit of advanced [students]"), an extensive commentary on the Siddhāntakaumudī.

Bhațtoji Dīkșita is widely known for his Siddhāntakaumudī. This work does indeed represent a turning point in the Sanskrit grammatical tradition: it is the most accomplished arrangement of Pāninian rules by topic (or prakriyā, cf. $\S 1.2$ "Grammar"). Grammars arranged by topic are mainly organized according to kinds of pada: the rules which introduce constituent units of one kind of pada as well as the rules which teach operations which apply inside the pada's boundaries are gathered together (contrary to the Asțādhyāyz, cf. §2.1.2). The Siddhāntakaumudī brought the prakriya method to such a level of refinement-including all the Pāṇinian rules, but also Kātyāyana's vārttikas and some of Patañjali's observations - that it was very successful and eclipsed Pāṇini's grammar itself (Indian scholars who are traditionally trained today still learn grammar through the Siddhāntakaumudī first).

\subsubsection{Nāgeśa's works}

Nāgeśa (late $17^{\text {th }}$ century, early $18^{\text {th }}$ century) is traditionally considered the last great representative of the Pāninian school. He is the author of several works, some related to grammar and some others related to disciplines such as poetry, dialectics and yoga. His grammatical works include commentaries, such as the Uddyota ("The Light [of the lamp of the Great commentary]") which is a commentary on Kaiyata's Pradipa and the Śabdenduśekhara ("The moon crest of words") which is a commentary on Bhattoji Dīkșita's Praudhamanoramā, but also independant treatises, such as the Paribhāṣenduśekhara ("The moon crest of metarules") which critically examines 133 metarules, as well as the Vaiyākaranasiddhāntamañjūṣa ("The chest of grammarians' conclusions", in three recensions 
of different length), which provides a synthesis of the main ideas related to the philosophy of grammar, ideas initiated by Patañjali and largely developped by Bhartṛhari.

Faithful to the Pāninian tradition, Nāgeśa nevertheless does not hesitate to make reference to some ideas from other disciplines. For instance, when he describes the word-meaning relation as being threefold - primary (śakti), secondary (lakșaṇa), suggestive (vyañjanāa) - he makes reference to a classification initially found in poetry and, saying that śakti is threefoldconventional (rüdhi), derivative (yoga), conventional-derivative (yogarüdhi) - he makes reference to a classification initially found in dialectics (note that grammarians disagree with both of these views, cf. §2.2.3). In his Sphoțavāda, an independent treatise on sphoța, Nāgeśa defines sphota as "that from which the meaning bursts forth" and mentions an eightfold classification of it: 1) phoneme, 2) word, 3) sentence, 4) indivisible word, 5) indivisible sentence, 6) phoneme-universal, 7) word-universal, 8) sentence-universal (for more details on this classification, cf. Matilal 1990: 104). Nāgeśa indicates that this classification presents the conceptions of grammarians regarding sphota but, in his Paramalaghumañjūs $\bar{a}$, he says that the sentence-sphota is the most important. According to Bronkhorst (1998b: 383), Nāgeśa's vacillations regarding sphota can be explained by the conflict which lies between two grammatical views: 1) grammatical derivations, for several reasons, cannot presuppose that stems and affixes are imaginary units $v s 2$ ) only the sentence is real.

\subsection{Main topics addressed}

\subsubsection{Minimal meaning-bearer units}

The search for minimal meaning-bearer units - brought together with the question of their real existence - has been a topic of great interest, for grammarians as well as for thinkers from other schools (cf. Bronkhorst 1998b: 380-383).

Some thinkers claimed that phonemes are meaning-bearers (cf. Vākyapadīya stanza 2.62: "Just as a minute perceptible object, when associated with something else, is perceived with it, in the same way, a phoneme becomes expressive [of a meaning] when it is associated with other phonemes", translation by Subramania Iyer 1977). For Pānini and some other grammarians, the minimal meaning-bearer units are verbal roots, nominal stems and affixes: arthavad adhātur apratyayah prätipadikam (1.2.45) "[The unit] which is meaningful, which is neither a verbal root nor an affix [is called] prātipadika ('nominal stem')" (italics are mine). Some other thinkers consider that finished words (śabda or pada) are meaning-bearer units; this view can be inferred from definitions of the sentence such as "[the sentence is] a collection of words" (śabdasamghätah) or "[the sentence is] the first word" (padam ädyam), which are quoted by Bhartrihari in his Vākyapadiya (stanzas 2.1-2). What is interesting to note regarding such conceptions is the analysis of the way words express their meaning within the sentence of which they are part. According to one analysis (called abhihitänvaya), the words of a sentence first convey their own meaning; these meanings subsequently relate syntactically to each other and produce the sentence meaning. According to another analysis (called anvitäbhidhāna), the words of a sentence convey their own meaning as well as their syntactic relation to each other (for more details on these analyses, cf. Kunjunni Raja 1963, chapter 5). According to Bhartrhari and some later grammarians (such as Nāgeśa, cf. §2.1.6), the minimal meaning-bearer unit is the vākya-sphoța, i.e. the sentence-sphota (cf. §2.1.4).

\subsubsection{Classes of words}

The analysis of language into units seems to have been fundamental in all traditions of language study. Indeed, in each Vedāinga related to language as well as in the other Sanskrit language sciences, one finds at least one classification of words (pada). 
Classifying words is an activity which is neither self-explanatory nor consistent: the classifier (whether an individual scholar, a school of thought, or a trend) has an epistemological aim and we must consider the regularities (in other words, the classes) established on this basis. An accurate study (cf. Aussant 2016a) shows that words (and nouns especially) are more often classified according to semantic criteria in the language sciences of premodern India. This can be explained by the importance given to the relation between the word and its meaning: what understanding a word triggers and how it does so constitutes a central topic of thought for ancient Indian theoreticians of language. Moreover, and unsurprisingly, one notes that grammar resorts to the widest range of word classifications, according to criteria which are: 1) formal (for instance, the Pāninian distinction between noun- $s U B$-anta "[A unit] that terminates in a nominal [ending]" - and verb - $t i \dot{N}$-anta "[A unit] that terminates in a verbal [ending]" - and their 29 subclasses, cf. Aussant 2016b), 2) semantic, i.e. ontological (nouns denoting a class, a quality, an action or a substance) and semiological (words having a generic property, a quality, an action or the wish of the speaker as connotation), 3) pragmatic (for instance, the distinction between words of spoken language- $b h \bar{a} s \underline{a}$ - and words of sacred literature-chandas-).

\subsubsection{Relation between word and meaning}

According to premodern Indian thinkers, the "designating relation" (vrtti) may have two forms: 1) a primary designating relation, called śakti (by grammarians and dialecticians), abhidha (by exegetes and poeticians) or still mukhya, 2) a secondary designating relation, called lakșaña or gauna. Grammarians and exegetes consider the primary designating relation as being innate (autpattika), natural (svābhāvika) and not relying on a soul (apaurușeya) ${ }^{13}$ dialecticians, on the contrary, consider it as being dependent on a convention (samketa), divine (according to ancient dialecticians) or human (according to neo-dialecticians). Unlike other thinkers, grammarians uphold that the word has only one designating relation (the śakti), whatever its uses: secondary or figurative meaning does not result from any particular signification function. Some later Pāṇinīyas like Nāgeśa explain the difference between various meanings of a word - which are all considered as primary - saying that some are well-known (prasiddha) while others are not or less well-known (aprasiddha), cf. Aussant 2014a: 29-30.

\subsubsection{Primary referent of nouns}

The ongoing question related to the primary referent of nouns-whatever the school of premodern Indian thinkers is, with the exception of Buddhist logicians, cf. Kunjunni Raja (1963: 78-94) - has been to determine whether this primary referent was particular (e.g. "cow" denotes a specific cow) or universal (e.g. "cow" denotes cowness). Different key issues are tightly related to this question, such as the relation between language and reality (in the case of evolutive referents or referents which do not yet exist — "weave a cloth!" - in the case of general rules or Vedic injunctions, etc.) or the nature of the primary designating relation (natural or conventional, cf. §2.2.3).

Different views have been claimed by grammarians: some, like Vyāḍi (cf. Scharfe 1977: 124126), considered that the primary referent of a noun is the particular (dravya); some others, like Vājapyāyana, considered that it is the universal or the generic property (jāti) while some others, like Patañjali, considered that it is both the particular and the universal/generic property, one being principal and the other subordinate according to the speaker intention (vivakșa). In addition to these three cardinal theses, some other views were discussed by

\footnotetext{
13 This did not prevent grammarians from thinking about issues related to conventional relations, such as proper names and metalinguistic terms. See Aussant (2009) for more details on this point.
} 
grammarians: a) the noun would denote the generic property, the individual and the gender, b) it would denote these three items plus the number, c) it would denote these four items plus the semantic role the noun takes on within the sentence (cf. Aussant 2014b: 273-275). According to dialecticians of the old school, a noun primarily denotes the particular (vyakti), its generic configuration $(\bar{a} k r t i)$ and its generic property (jâti); dialecticians of the new school slightly modify this view (cf. Kunjunni Raja 1963: 70-71). According to exegetes, the noun primarily denotes the class property ( $\bar{a} k r t i)$, which is common to all the particular instances of one class and only to them. For more details about the denotation of (generic) nouns, see Scharf (1996).

\section{Bibliography}

- Abhyankar, K.V., 1974. Veda-padapātha-carcā, together with the text of Upalekhasūtram of Bhāradvāja Bṛhaspati edited with explanation in English, Poona, Bhandarkar Oriental Research Institute.

- Abhyankar, K.V. and Devasthali, G.V., 1978. Vedavikrtilakṣana-samgraha (A collection of twelve tracts on Vedavikrtis and allied topics), Compiled and critically edited with Introduction and variant readings, Poona, Bhandarkar Oriental Research Institute.

- Allen, W.S., 1953. Phonetics in Ancient India, London, Oxford University Press.

- Auroux, S., 1992. "Le processus de grammatisation et ses enjeux", in Auroux, S. (ed.), Histoire des idées linguistiques vol. II, Liège, Mardaga, pp.11-64.

- Auroux, S., 1994. La révolution technologique de la grammatisation, Liège, Mardaga.

- Arjunwadkar, K.S., 1992. Marathi Vyakaranaca Itihas [A history of Marathi Grammar], Mumbai, Mumbai Vishva Vidyalay.

- Aussant, E. 2009. Le nom propre en Inde. Considérations sur le mécanisme référentiel, Lyon, ENS Editions.

- Aussant, E., 2012. "Pāṇinian Features of the Oldest Known Malayālam Description", in Cardona, G., Aklujkar, A. and Ogawa, H. (eds.), Studies in Sanskrit Grammars - Proceedings of the Vyākarana Section of the 14th World Sanskrit Conference, New Delhi, D.K. Printworld, pp.87-101.

- Aussant, E., 2014a. "Sanskrit Theories on Homonymy and Polysemy", Bulletin d'Études Indiennes 32, pp.13-36.

- Aussant, E., 2014b. "Les grammairiens indiens du sanskrit et le sens des mots", in Archaimbault, S., Fournier, J.-M. \& Raby, V. (dir.), Penser l'histoire des savoirs linguistiques. Hommage à Sylvain Auroux, Lyon, ENS Éditions, pp.273-283.

- Aussant, E., 2016a. Classifications of words in traditional Sanskrit grammar and related disciplines. Habilitation (HDR) dissertation. $95 \mathrm{p}$.

- Aussant, E., 2016b. "Classifications of Words in Ancient Sanskrit Grammars", in History of Linguistics 2014: Selected papers from the 13th International Conference on the History of the Language Sciences (ICHoLS XIII), Vila Real, Portugal, 25-29 August 2014, ed. by C. Assunção, G. Fernandes \& R. Kemmler, Amsterdam \& Philadelphia, John Benjamins, Studies in the History of the Language Sciences 126, pp.97-109.

- Aussant, E. (dir.), 2017. "La Grammaire Sanskrite Étendue" (thematic issue), Histoire Epistémologie Langage 39.2.

- Aussant, E., forthcoming. "Les pada et leurs classifications : un point d'entrée pour étudier l'émergence et le développement de la tradition grammaticale sanskrite", in Aussant, É. and Colas, G. (eds.), Les scolastiques indiennes: naissances, développements, interactions, Paris/Pondicherry, EFEO/IFP. 
- Balbir, N., 2000. Notices from the Corpus des Textes Linguistiques Fondamentaux (http://ctlf.ens-lyon.fr): Vararuci (notice 4331), Purușottama (notice 4335), Hemacandra (notice 4336), Mārkaṇ̣eya (notice 4340).

- Bandyopadhyay, A., 2011. A History of Bengali Grammar, Delhi, Sanskrit Pustak Bhandar.

- Belvalkar, S.K., 1915. An account of the different existing systems of Sanskrit grammar, Poona, Aryabhushan Press.

- Bhatia, T., 1987. A History of the Hindi Grammatical Tradition - Hindi-Hindustani Grammar, Grammarians, History and Problems, Leiden, E.J. Brill.

- Bhide, P.R., 2015. IC Analysis in Modern Sanskrit Lexicography with special reference to Encyclopaedic Dictionary of Sanskrit on Historical Principles, PhD Thesis (Dir.: M. Kulkarni), Indian Institute of Technology Bombay, Department of Humanities and Social Sciences.

- Bloomfield, L., 1933. Language, New York, Henry Holt.

- Bronkhorst, J., 1998a. "Patañjali", in Craig, E. (ed.), Routledge Encyclopedia of Philosophy vol. 7, pp.248-250.

- Bronkhorst, J., 1998b. "Indian Theories of Language", in Craig, E. (ed.), Routledge Encyclopedia of Philosophy vol. 7, pp.379-384.

- Bronkhorst, J., 1998c. "Bhartṛhari", in Craig, E. (ed.), Routledge Encyclopedia of Philosophy vol. 7, pp.764-766.

- Bronkhorst, J., 2014. "Deviant voices in the history of Pāninian grammar", Bulletin d'Études Indiennes 32, pp.47-53.

- Bronner, Y., 2012. "Sanskrit Poetics", in Greene, R. and Cushman, S. (eds.), The Princeton Encyclopedia of Poetry and Poetics, 4th ed., Princeton, Princeton University Press, pp.12441250 .

- Cardona, G., 1980. Pānini - A survey of research, Delhi/Varanasi/Patna, Motilal Banarsidass ( $1^{\text {st }}$ ed.: The Hague, Mouton, 1976).

- Cardona, G., 1997. Pānini. His work and its traditions, volume I: Background and Introduction, $2^{\text {nd }}$ revised and completed edition, Delhi, Motilal Banarsidass $\left(1^{\text {st }}\right.$ edition: 1988).

- Cardona, G., 2008. "Theoretical Precedents of the Kātantra”, in Kaul, M. and Aklujkar, A. (eds.), Linguistic Traditions of Kashmir. Essays in Memory of Pandit Dinanath Yaksh, New Delhi, D.K. Printworld, pp.300-367.

- Cardona, G., 2009. "Bhartṛhari and Patañjali: Traditions Preserved", in Chaturvedi, M. (ed.), Bhartrhari, Language, Thought and Reality, Delhi, Motilal Banarsidass, pp.119-161.

- Cardona, G., 2012. "Pāṇini and Padakāras", in F. Voegeli, V. Eltschinger, D. Feller, M.P. Candotti, B. Diaconescu \& M.A. Kulkarni (ed.) Devadattīyam - Johannes Bronkhorst Felicitation Volume, Bern, Peter Lang, pp.39-61.

- Cardona, G., 2014. "Segmentation of Vedic texts : padapāṭas", Bulletin d'Études Indiennes 32 (Proceedings of the workshop "The Indian Traditions of Language Studies", ICHoLS XI, Potsdam, ed. by É. Aussant and J.-L. Chevillard), pp.87-100.

- Cardona, G. and Jain, D., 2007. The Indo-Aryan Languages, London \& New York, Routledge, Language Family Series ( $1^{\text {st }}$ ed.: 2003).

- Chevillard, J.-L., 2000a. "Les débuts de la tradition linguistique tamoule", in Auroux, S., Koerner, E.F.K, Niederehe, H.-J. and Versteegh, K. (eds.), History of the Language Sciences, An International Handbook on the Evolution of the Study of Language from the Beginnings to the Present, Berlin/New York, Walter de Gruyter, pp.191-194.

- Chevillard, J.-L., 2000b. "Le Tolkāppiyam et le développement de la tradition linguistique tamoule", in Auroux, S., Koerner, E.F.K, Niederehe, H.-J. and Versteegh, K. (eds.), History of the Language Sciences, An International Handbook on the Evolution of the Study of 
Language from the Beginnings to the Present, Berlin/New York, Walter de Gruyter, pp.194200.

- Chevillard, J.-L., 2000c. "Les successeurs du Tolkāppiyam : le Nannūl, le Vīracōliyam et les autres écoles", in Auroux, S., Koerner, E.F.K, Niederehe, H.-J. and Versteegh, K. (eds.), History of the Language Sciences, An International Handbook on the Evolution of the Study of Language from the Beginnings to the Present, Berlin/New York, Walter de Gruyter, pp.200-202.

- Chevillard, J.-L., 2000d. Notices from the Corpus des Textes Linguistiques Fondamentaux (http://ctlf.ens-lyon.fr): Tolkāppiyanār (notice 4351), Iḷampūraṇar (notice 4352), Puttamittiranār (notice 4353), Kuṇavīrapaṇțitar (notice 4354), Pavaṇanti Munivar (notice 4355), Mayilai Nātar (notice 4356), Cēn̄āvaraiyar (notice 4357), Naccināākkininyar (notice 4358), Cuppiramaṇiya Tīṭcitar (notice 4359), Civañāna Munivar (notice 4360).

- Chevillard, J.-L., 2009. "Elementary Grammatical Devices in Classical Tamil Grammar", in Hummel, P. (ed.), Epilanguages, Beyond Idioms and Languages, Paris, Editions Philologicum.

- Coward, H.G., 1980. The sphota Theory of Language, Delhi/Varanasi/Patna, Motilal Banarsidass.

- Coward, H.G. and Kunjunni Raja, K. (eds.), 1990. Encyclopedia of Indian Philosophies Vol. V, The Philosophy of the Grammarians, Delhi/Varanasi/Patna/Bangalore/Madras, Motilal Banarsidass.

- David, H., to be published. "Les définitions de l'énoncé (vākya) dans la tradition sanskrite : entre grammaire et exégèse", in Raby, V. (dir.), "L'énoncé dans les traditions linguistiques : logos, vākya, kalām, oratio et les autres", Langages 205 (2017/1).

- De, S.K., 1960. History of Sanskrit Poetics, Calcutta, K.L. Mukhopadhyay, 2 vols.

- Deshpande, M.M., 1998. "Evolution of the notion of authority (prāmānya) in the Pāninian tradition", Histoire Épistémologie Langage 20.1, pp.5-28.

- Deshpande, M.M., 2000. "Indian Theories on Phonetics", in Auroux, S., Koerner, E.F.K., Niederehe, H.-J., Versteegh, K. (eds.), History of the Language Sciences, An International Handbook on the Evolution of the Study of Language from the Beginnings to the Present, Berlin/New York, Walter de Gruyter, pp.137-146.

- Emeneau, M.B., 1988. "Bloomfield and Pāṇini”, Language 64.4, pp.755-760.

- Ezhuthachan, K.N., 1975. The history of the grammatical theories in Malayalam (part I), Trivandrum, Dravidian Linguistics Association.

- Gaurinath Sastri, 1980. A study in the Dialectics of Sphota, Delhi, Motilal Banarsidass.

- Gerow, E., 1971. Indian Poetics, Wiesbaden, O. Harrassowitz (A History of Indian Literature).

- Gerschheimer, G., 1996. La théorie de la signification chez Gadādhara, 2 vol., Paris, Publications de l'Institut de civilisation indienne, Diffusion De Boccard.

- Gillon, B., 2007. "Pāṇini's Aștâdhyāyȳ and Linguistic Theory", Journal of Indian Philosophy 35.5, pp.445-468.

- Grierson, A.G., 1918. "The Prakrit Vibhasa”, Journal of the Royal Asiatic Society, pp. 489517.

- Harris, Z., 1954. "Transfer Grammar”, International Journal of American Linguistics 20.4, p. 259-270.

- Hock, H.H., 2016. "Indo-Aryan grammatical traditions (Sanskrit and Prakrit)", in Hock, H.H. and Bashir, E. (eds.), The Languages and Linguistics of South Asia - A comprehensive guide, Berlin, De Gruyter, p. 707-716.

- Jha, G., 1942. Pūrvā-Mìmāmsā in Its Sources, with a critical bibliography by U. Mishra, Benares, Benares Hindu University (Library of Indian Philosophy and Religion, 1).

- Jha, V.N., 1987. Studies in the Padapāthas and Vedic Philology, Delhi, Pratibha Prakashan. 
- Jha, V.N., 1992. A Linguistic Analysis of the Rgveda-Padapātha (Pre-Pāninian Grammatical Traditions, Part I), Delhi, Sri Satguru Publications.

- Kahrs, E., 1998. Indian Semantic Analysis: The Nirvacana Tradition, Cambridge, Cambridge University Press (Oriental Publications 55).

- Kulkarni, N.R., 1995. A Grammatical Analysis of the Taittirìya-Padapātha (Pre-Pāninian Grammatical Traditions, Part II), Delhi, Sri Satguru Publications.

- Kulli, J.S., 1991. History of Grammatical Theories in Kannada, Tiruvanantapuram.

- Kulli, J.S., 1997. "Grammars-Kannada", in Subramoniam, V.I. (ed.), Dravidian Encyclopedia Vol. III, Thiruvananthapuram, pp.244-246.

- Kunjunni Raja, K., 1963. Indian Theories of Meaning, Madras, The Adyar Library and Research Center.

- McCrea, L., 2000. "The Hierarchical organization of language in Mīmāṃsā interpretive theory", Journal of Indian Philosophy 28, pp.429-459.

- Macdonell, A.A., 1995. A Vedic Grammar for Students, Delhi, Motilal Banarsidass (1 ${ }^{\text {st }}$ Indian edition: 1993; $1^{\text {st }}$ edition: 1916, Oxford, The Clarendon Press).

- Matilal, B.K., 1977. Nyāya-Vaiśeșika, Wiesbaden, O. Harrassowitz (A History of Indian Literature).

- Matilal, B.K., 1990. The Word and the World. India's Contribution to the Study of Language, Oxford, Oxford University Press.

- Meenakshisundaram, T.P., 1974. Foreign Models in Tamil Grammar, (= Dravidian Linguistics Association Publication, 15), Trivandrum, University of Kerala.

- Miller, Roy A., 2000. "The Establishment of Tibetan Linguistics", in Auroux, S., Koerner, E.F.K, Niederehe, H.-J. and Versteegh, K. (eds.), History of the Language Sciences - An International Handbook on the Evolution of the Study of Language from the Beginnings to the Present vol. I, p. 203-206.

- Mone, M.S., 1927. Marathiche Vyakarankar ani Vyakaran-prabandhakar [Marathi's Grammarians], Pune, Shrimant Holkar Sarkar Granthamala.

- Nitti-Dolci, L., 1938. Les grammairiens prakrits, Paris, Adrien-Maisonneuve.

- Patkar, M.M., 1981. History of Sanskrit Lexicography, Delhi, Munshiram Manoharlal.

- Pinault, G.-J., 1989. "Le système de Pāṇini”, in Auroux, S. (ed.), Histoire des idées linguistiques Tome 1 ("La naissance des métalangages en Orient et en Occident"), Liège, Mardaga, pp.371-400.

- Pollock, S., 2007. The language of the Gods in the world of men. Sanskrit, culture and power in premodern India, Delhi, Permanent Black ( $1^{\text {st }}$ ed.: University of California Press, 2006).

- Purushottam, Boddupalli, 1996. The Theories of Telugu Grammar, Tiruvanantapuram.

- Raghavan, V., 1974. "How many grammars?", in Chatterji, S.K. et al. (eds.), Charudeva Shastri Felicitation Volume: Presented to Prof. Charudeva Shastri on the Occasion of His Seventy-fifth Anniversary by his Friends and Admirers, Delhi, Charudeva Shastri Felicitation Committee, pp.271-278.

- Renou, L., 1947. Les écoles védiques et la formation du Veda, Paris, Cahiers de la Société Asiatique 9.

- Rogers, D.E., 1987. "The influence of Pāṇini on Leonard Bloomfield", Historiographia Linguistica 14.1/2, pp.89-138.

- Salomon, R., 1982. "The Ukti-Vyakti-Prakarana as a Manual of spoken Sanskrit”, IndoIranian Journal 24.1, pp.13-25.

- Sarveswara Sharma, P., 1973. "What the native grammarians say about Telugu language", Zeitschrift der deutschen morgenländischen Gesellschaft, Supplement II.XVIII, Leipzig/Wiesbaden, Deutscher Orientalistentag, pp.384-389. 
- Scharf, P.M., 1996. The Denotation of Generic Terms in Ancient Indian Philosophy: Grammar, Nyāya, and Mīmāmnsāa, Philadelphia, American Philosophical Society.

- Scharfe, H., 1977. Grammatical Literature, Wiesbaden, O. Harrassowitz (A History of Indian Literature).

- Shapiro, M.C., 2000. "The Hindi grammatical tradition", in History of the Language Sciences - An International Handbook on the Evolution of the Study of Language from the Beginnings to the Present vol. I, pp.178-181.

- Subrahmanya Sastri, P.S., 1997. History of Grammatical Theories in Tamil, Chennai, The Kuppuswami Sastri Research Institute.

- Subramanya Iyer, K.A., 1977. The Vākyapadīya of Bhartrhari, Kānḍa II, English Translation with Exegetical Notes, Delhi/Varanasi/Patna, Motilal Banarsidass.

- Subramanya Iyer, K.A., 1992. Bhartrhari - A study of the Vākyapadīya in the light of ancient commentaries, Poona, Deccan College (Deccan College Building Centenary and Silver Jubilee Series 68).

- Thieme, P., 1982-1983. "Meaning and form of the 'grammar' of Pānini”, Studien zur Indologie und Iranistik 8/9, pp.3-34.

- Vergiani, V., 2013. "The adoption of Bhartṛhari's classification of the grammatical object in Cênāanaraiyar's commentary on the Tolkapppiyam", in Cox, W. and Vergiani, V. (eds.), Pondicherry, Institut français de Pondichéry \& École française d'Extrême-Orient, pp.161-197.

- Verhagen, P.C., 2000a. "The classical Tibetan grammarians", in Auroux, S., Koerner, E.F.K, Niederehe, H.-J. and Versteegh, K. (eds.), History of the Language Sciences - An International Handbook on the Evolution of the Study of Language from the Beginnings to the Present vol. I p. 207-210.

- Verhagen, P.C., 2000b. "The influence of the Sanskrit tradition on Tibetan indigenous grammar", in Auroux, S., Koerner, E.F.K, Niederehe, H.-J. and Versteegh, K. (eds.), History of the Language Sciences - An International Handbook on the Evolution of the Study of Language from the Beginnings to the Present vol. I p. 210-214.

- Verpoorten, J.-M., 1987. Mìmāmsā Literature, Wiesbaden, O. Harrassowitz (A History of Indian Literature).

- Vogel, C., 1979. Indian Lexicography, Wiesbaden, O. Harrassowitz (A History of Indian Literature).

- Zwartjes, O., 2011. Portuguese Missionary Grammars in Asia, Africa and Brazil, 15501800, Amsterdam/Philadelphia, John Benjamins (Studies in the History of the Language Sciences 117).

- Zwartjes, O. and Pytlowany, A., forthcoming. "Pre-modern Descriptions in Dutch of Languages in India: Ketelaar's grammar of Hindustani (1698) and Rüell's grammar of Sinhala (1700)". 